\title{
KARAKTERISTIK KEPITING KERACA Thalamita sp. HASIL TANGKAPAN SAMPING NELAYAN DI KOTA TARAKAN SEBAGAI BAHAN BAKU PANGAN BERGIZI
}

\author{
Novi Luthfiyana ${ }^{1 \star}$, Stephanie Bija ${ }^{1}$, Heni Irawati ${ }^{2}$, Awaludin $^{3}$, Andi Ramadani ${ }^{1}$ \\ ${ }^{1}$ Departemen Teknologi Hasil Perikanan, Fakultas Perikanan dan Ilmu Kelautan Universitas Borneo \\ Tarakan, Kalimantan Utara \\ ${ }^{2}$ Departemen Manajemen Sumberdaya Perairan, Fakultas Perikanan dan Ilmu Kelautan Universitas \\ Borneo Tarakan, Kalimantan Utara \\ ${ }^{3}$ Departemen Akuakultur, Fakultas Perikanan dan Ilmu Kelautan Universitas Borneo Tarakan, \\ Kalimantan Utara
}

Diterima: 24 November 2020/Disetujui: 12 Juli 2021

^Korespondensi: luthfiyananovi@gmail.com

Cara sitasi: Luthfiyana N, Bija S, Irawati H, Awaludin, Ramadani A. 2021. Karakteristik kepiting keraca Thalamita sp. hasil tangkapan samping nelayana di Kota Tarakan sebagai bahan baku pangan bergizi. Jurnal Pengolahan Hasil Perikanan Indonesia. 24(2): 188-199.

\begin{abstract}
Abstrak
Kepiting keraca (Thalamita sp.) adalah salah satu genus terbesar dalam sub-famili Portunidae yang memiliki ukuran kecil dan harga yang murah bila dibandingkan dengan jenis kepiting yang lainya. Kepiting keraca merupakan hasil tangkapan samping (HTS) nelayan di kota Tarakan yang dikembangkan sebagai bahan baku pangan. Tujuan penelitian ini adalah menentukan komposisi kimia, profil asam lemak, dan kandungan logam berat kepiting keraca. Sampel yang digunakan dalam penelitian ini adalah keseluruhan dari kepiting keraca kecuali capit dan karapas. Hasil penelitian menunjukkan bahwa komposisi kimia kepiting keraca basis basah mengandung kadar air 70,05\% kadar protein 9,887\%, kadar lemak 0,25\%, kadar abu $13,02 \%$, serat kasar 2,52\% dan karbohidrat sebesar 6,84\%. Kepiting keraca basis basah memiliki asam lemak jenuh (SFA) sebesar 12,64\%, asam lemak tak jenuh tunggal (MUFA) 5,46\% dan asam lemak tak jenuh jamak (PUFA) yaitu $8,73 \%$. Kandungan logam berat $\mathrm{Cd}, \mathrm{Hg}$, dan $\mathrm{Pb}$ dari kepiting keraca masih di bawah baku mutu SNI. Kepiting keraca hasil tangkapan samping nelayan terbukti aman digunakan sebagai bahan pangan dan bergizi.
\end{abstract}

Kata kunci: asam lemak, logam berat, proksimat, PUFA

\section{Fisheries By-Catch at Tarakan City as a source of Nutritious Food}

\begin{abstract}
Mottled swimming crab (Thalamita sp.) is one of the largest genus in the Portunidae subfamily having a smaller size and lower price compared to the other types of crab. Mottled swimming crab is a by-catch of fishermen in the Tarakan city and could be developed as a food source. The purpose of this study was to determine chemical composition, fatty acid profile and heavy metal content of mottled swimming crab. Whole body of the crab except claws and carapace was analyzed. The results showed mottled swimming crab contained $70.05 \%$ moister, $9.89 \%$ protein, $0.25 \%$ fat, $13.02 \%$ ash, $2.52 \%$ crude fiber and $6.84 \%$ carbohydrates content. The crab contained saturated fatty acids (SFA) amounted to $12.64 \%$, monounsaturated fatty acids (MUFA) $5.46 \%$ and polyunsaturated fatty acids (PUFA) $8.73 \%$. The content of Cd, $\mathrm{Hg}$ and $\mathrm{Pb}$ was still below the maximum limit allowed by Indonesian National Standard. The Keraca crab is proven to be safe to use as food and nutritious.
\end{abstract}

Keyword: fatty acids, heavy metals, proximate, PUFA 


\section{PENDAHULUAN}

Perairan Tarakan merupakan daerah penangkapan sumber daya ikan potensial di Kalimantan Utara (Bonte dan Firdaus 2012). Tiga alat tangkap yang dominan digunakan dalam kegiatan perikanan tangkap di Kota Tarakan adalah pukat tarik, tugu serta kelong, dengan target hasil tangkapan utama berupa udang dan ikan demersal (Firdaus 2010). Penggunaan alat tangkap yang kurang selektif mengakibatkan banyak ikan yang bukan menjadi target utama yaitu selain ikan nomei, udang dan cumi-cumi ikut terbawa dalam penangkapan dan menjadi hasil tangkapan samping (Agus et al. 2012). Salah satu hasil tangkapan samping nelayan di kota Tarakan dengan alat tangkap pukat tarik dan jumlahnya cukup melimpah sehingga banyak dimanfaatkan oleh beberapa UKM adalah kepiting keraca (Thalamita sp.).

Genus Thalamita adalah salah satu marga terbesar dalam anak suku Portunidae dan setidaknya 66 spesies telah ditemukan di Indo-Pasifik Barat. Thalamita sp ditemukan di dasar laut bersubstrat batu karang, berpasir, berlumpur dan di kawasan bakau serta lamun (Wahyudi 2008; Pratiwi 2010; Anggraeni et al. 2015; Muhd-Farouk et al. 2017; Hamid et al. 2019). Distribusi Thalamita sp. mulai daerah pasang surut hingga kedalaman $100 \mathrm{~m}$ (Anggorowati 2014). Lebar karapas jantan lebih besar bila dibandingkan dengan yang betina (Norman 1996). Marga Thalamita termasuk dalam ukuran kepiting kecil dan saat ini diperdagangkan secara lokal (Sawusdee dan Songrak et al. 2009).

Kepiting keraca dimanfaatkan oleh Usaha Kecil Menengah (UKM) di Kota Tarakan sebagai bahan baku olahan pangan seperti kepiting goreng, kerupuk, serta petis. Produk olahan berbahan baku kepiting memiliki prospek dan segmen pasar potensial untuk dikembangkan sebagai produk oleholeh khas kota Tarakan, namun informasi mengenai kandungan gizi dan keamanan pangan kepiting keraca belum diketahui karena belum pernah dilakukan pengujian sebelumnya. Kandungan gizi kepiting keraca dapat dilakukan dengan melihat komposisi kimia yang terkandung di dalamnya melalui uji proksimat. Pengujian profil asam lemak dilakukan untuk mengetahui kandungan asam lemak jenuh dan tidak jenuh yang ada pada kepiting keraca. Pengujian logam berat berupa kadmium $(\mathrm{Cd})$, merkurium $(\mathrm{Hg})$ dan timbel $(\mathrm{Pb})$ perlu dilakukan untuk mengetahui persyaratan mutu dan keamanan pangan yang mengacu pada Standar Nasional Indonesia (SNI). Dengan adanya pengujian kandungan gizi dan keamanan pangan dari kepiting keraca, diharapkan dapat meningkatkan nilai konsumsi, serta mengetahui potensi pengembangan yang tepat dalam pemanfaatannya. Penelitian ini bertujuan menentukan komposisi kimia, profil asam lemak, dan kandungan logam berat kepiting yang merupakan hasil tangkapan samping nelayan di Kota Tarakan.

\section{BAHAN DAN METODE Bahan dan Alat}

Bahan utama yang digunakan pada penelitian ini adalah kepiting keraca (Thalamita sp.) Bahan lain yang digunakan dalam penelitian adalah akuades (Brataco, Indonesia), asam sulfat (Merck, Jerman), asam klorida 0,1 N (Merck, Jerman), alkohol $70 \%$ (Merck, Jerman), $\mathrm{H}_{2} \mathrm{SO}_{4}$ (Merck, Jerman), $\mathrm{K}_{2} \mathrm{SO}_{4}$ (Merck, Jerman). Alat yang digunakan dalam penelitian ini adalah penggaris, cawan tembikar, atomic absorption spectrophotometer (AAS) (Shimadzu AA 7000, Jepang), timbangan digital (Tanita $\mathrm{KD}-160$, Indonesia), timbangan analitik tipe 210-LC (Adam, Amerika Serikat), laminary air flow (Biosafety BH 2000, Jerman), alatalat gelas (Pyrex, Amerika Serikat), blender (Philips HR2116, Belanda), inkubator $37^{\circ} \mathrm{C}$ (Memmert, Jerman), UN55 oven pengering (Memmert, Jerman), desikator (Duranpart bowl, Jerman), tanur (Muffle Furnace, Jerman), kromatografi gas (Shimadzu GC2014, Jepang).

\section{Metode Penelitian}

Penelitian ini terdiri dari tiga tahap. Tahap pertama adalah pengambilan sampel kepiting keraca. Tahap kedua identififikasi karakteristik morfologi dari kepiting keraca dengan melakukan pengukuran dan penimbangan. Tahap ketiga adalah preparasi sampel sebelum dilakukan analisis untuk 
mengetahui kandungan proksimat, profil asam lemak dan kandungan logam berat pada sampel kepiting keraca.

\section{Pengambilan sampel kepiting keraca}

Pengambilan sampel kepiting keraca dilakukan pada awal Januari tahun 2020 pada saat musim penghujan. Kepiting keraca yang diperoleh dari hasil tangkapan samping nelayan di kota Tarakan menggunakan alat tangkap pukat tarik. Sampel yang diperoleh masih dalam keadaan hidup dan segar, sehingga dilakukan pemisahan terlebih dahulu dengan ikan hasil tangkapan utama nelayan yaitu ikan nomei, udang dan cumi-cumi. Kepiting keraca dibersihkan dengan air tawar, kemudian dimasukkan dalam kotak stirofoam yang berisi serpihan es, sehingga kepiting masih dalam keadaan segar selama proses transportasi menuju Laboratorium Fakultas Perikanan dan Ilmu Kelautan Universitas Borneo Tarakan yang membutuhkan waktu kurang lebih 30 menit.

\section{Pengukuran sampel kepiting keraca}

Jumlah sampel kepiting keraca yang digunakan dalam pengukuran ini sebanyak 20 sampel jantan dan 20 sampel betina dalam satu populasi. Penentuan jumlah sampel yang diukur berdasarkan jumlah seluruh sampel kepiting keraca terdiri dari 200 jantan dan 200 betina. Sugiono (2007), menyatakan untuk memperoleh sampel yang representatif, perlu untuk menentukan sampel yang jumlahnya sesuai dengan ukuran sampel yang akan dijadikan sumber data dengan memperhatikan sifat-sifat dan penyebaran populasinya. Pengambilan sampel dari populasi berkisar $10-15 \%$ atau $20-25 \%$.

Pengukuran panjang karapas dilihat dari jarak antara tepi duri frontal margin dengan tepi bawah karapas. Lebar karapas merupakan jarak antara ujung duri marginal terakhir di sebelah kanan dengan duri marginal terakhir di sebelah kiri. Pengukuran lebar karapas ini dilakukan, karena kepiting keraca memiliki lebar karapas yang lebih besar jika dibandingkan dengan panjang tubuhnya (Kanna 2002). Pengamatan jenis kelamin dilakukan dengan mengamati bentuk abdomen kepiting, jika mengerucut adalah jantan sedangkan betina melebar (Kasry 1996). Data yang diperoleh merupakan ratarata ukuran panjang, lebar dan berat serta deskriptif struktur morfologis tubuh kepiting keraca yang berbeda berdasarkan jenis kelamin.

\section{Preparasi sampel kepiting keraca}

Penelitian ini tidak menggunakan daging saja karena kepiting keraca yang diproduksi oleh UKM dan dikonsumsi seluruh bagian tubuhnya kecuali bagian karapas dan capit. Sampel kepiting keraca terlebih dahulu dibersihkan dari kotoran dan sisa-sisa pasir yang menempel dengan akuades. Kepiting keraca yang sudah bersih ditiriskan. Karapas dan kedua capit dari kepiting keraca dihilangkan. Sampel diletakkan dalam wadah kotak plastik tertutup dan disimpan beku. Sampel yang siap untuk dilakukan pengujian kemudian dihaluskan menggunakan blender dilanjutkan dengan proses pengujian proksimat, profil asam lemak dan logam berat untuk mengetahui kandungan gizi dan keamanan bahan bakunya.

\section{Analisis proksimat}

Analisis proksimat yang dilakukan terdiri atas: kadar protein, lemak, karbohidrat, air, abu, dan serat kasar. Penentuan kadar protein dilakukan menggunakan metode makro Kjeldahl, kadar lemak dilakukan dengan metode ekstraksi dan gravimetri. Kadar air dan abu dilakukan dengan metode gravimetri, sedangkan analisis kandungan karbohidrat dilakukan by difference. Selanjutnya pengujian serat kasar dilakukan dengan metode ekstraksi dan pencucian asam-basa. Analisis proksimat dilakukan sebanyak 2 kali ulangan.

\section{Protein}

Penentuan kadar protein menggunakan metode Kjeldahl berdasarkan SNI 012354.4-2006 (BSN 2006) dengan prinsip pelepasan nitrogen dari jaringan daging melalui destruksi. Senyawa nitrogen terikat oleh sulfat membentuk amonium sulfat. Selanjutnya amonium sulfat diubah menjadi garam basa $\mathrm{NH}_{4} \mathrm{OH}$ dengan penambahan $\mathrm{NaOH}$. Amonium hidroksida $\left(\mathrm{NH}_{4} \mathrm{OH}\right)$ yang terbentuk kemudian didestilasi menggunakan 
panas uap dengan suhu $\pm 105{ }^{\circ} \mathrm{C}$ untuk memisahkan senyawa amonia. Amonia ditangkap oleh asam borat membentuk amonium borat dan selanjutnya dilakukan titrasi dengan asam klorida hingga warna berubah dari hijau menjadi abu-abu netral (natural gray). Penetapan jumlah nitrogen dihitung secara stokiometri dan kadar protein diperoleh dengan mengalikan jumlah nitrogen dengan faktor konversi.

\section{Lemak}

Prinsip penentuan kadar lemak berdasarkan SNI 2354-3:2006 (BSN 2006) dilakukan menggunakan metode ekstraksi dalam pelarut organik dietil eter dengan bantuan pemanasan pada suhu $35^{\circ} \mathrm{C}$ titik didih pelarut selama 8 jam. Pelarut organik yang mengikat lemak selanjutnya dievaporasi menggunakan evaporator putar horizontal. Evaporasi merupakan proses pemisahan antara pelarut (solvent) dan zat terlarut (solute). Penetapan kadar lemak dilakukan secara gravimetri.

$\operatorname{Lemak}(\%)=\frac{\mathrm{w}-\mathrm{w} 1}{\mathrm{w} 2} \times 100 \%$

Keterangan:

W: Bobot sampel (g)

W1: Bobot lemak sebelum ekstraksi (g)

W2: Bobot labu lemak sesudah ekstraksi (g)

\section{Kadar air}

Molekul air dihilangkan melalui pemanasan dengan oven pada suhu $105{ }^{\circ} \mathrm{C}$ selama 16-24 jam. Penentuan berat air dihitung secara gravimetri berdasarkan SNI01-2354.2-2006 (BSN 2006), sehingga kadar air diperoleh dari selisih berat sampel sebelum dan sesudah sampel dikeringkan.

\section{Kadar abu}

Kadar abu ditentukan melalui metode gravimetri (AOAC 2005) dengan pembakaran dalam tanur pada suhu $600{ }^{\circ} \mathrm{C}$ selama 3 jam. Persentase dari kadar abu dihitung menggunakan rasio bobot abu dengan bobot sampel.

\section{Karbohidrat}

Penentuan kadar karbohidrat dilakukan dengan metode by difference dihitung dengan menggunakan rumus \%karbohidrat $=100$ ( $\%$ a ir $+\%$ protein $+\%$ le $m a k+\%$ abu ) berdasarkan SNI-01-2370-1991 (BSN 1991) tentang penentuan kadar karbohidrat.

\section{Serat kasar}

Serat kasar ditentukan dengan cara ekstraksi Soxhletasi atau dengan cara mengaduk, mengendap-tuangkan sampel dalam pelarut organik sebanyak 3 kali. Sampel kemudian dianalisis dengan pemansahan hingga mendidih yang disertai pencucian asam dan basa secara bergantian sesuai dengan SNI 01-2891-1992 (BSN 1992).

Serat $\operatorname{kasar}(\%)=\frac{\mathrm{w}-\mathrm{w} 1}{\mathrm{w} 2} \times 100 \%$

Keterangan:

W: Bobot sampel (g)

W1: Bobot abu (g)

W2: Bobot endapan pada kertas saring (g)

\section{Analisis profil asam lemak}

Analisis profil asam lemak dilakukan menggunakan alat kromatografi gas Shimadzu GC-2014 (Jepang) berdasarkan AOAC (2005). Sampel sebanyak $1 \mathrm{~mL}$ ditambahkan larutan boron tetrafluorida sebanyak $2 \mathrm{~mL}$ dalam metanol dan dipanaskan selama 65 menit pada suhu $65{ }^{\circ} \mathrm{C}$. Larutan kemudian ditambahkan $3 \mathrm{~mL}$ heksana dan dikocok hingga membentuk dua lapisan. Larutan heksana di bagian atas dipindahkan dengan bantuan pipet tetes ke dalam tabung reaksi. Sampel sebanyak $1 \mu \mathrm{L}$ diinjeksikan ke dalam alat kromatografi gas. Kondisi suhu awal kolom Cyanopropyl methyl sil (capillary column) $140{ }^{\circ} \mathrm{C}$, ditahan selama 5 menit, kemudian dinaikkan menjadi $240{ }^{\circ} \mathrm{C}$ dan suhu injektor $220^{\circ} \mathrm{C}$. Gas yang digunakan sebagai fase gerak adalah gas nitrogen, sedangkan gas pembakar adalah hidrogen dan oksigen. Laju alir gas hidrogen $40 \mathrm{~mL} / \mathrm{menit}$, nitrogen $30 \mathrm{~mL} / \mathrm{menit}$, dan oksigen $400 \mathrm{~mL} / \mathrm{menit}$. Puncak setiap fatty acid methyl ester (FAME) diidentifikasi dengan membandingkan waktu retensi dengan standar FEME Mix C8-C22. Komposisi masing-masing asam lemak dihitung berdasarkan luas puncak dari asam lemak yang muncul dalam kromatogram, dinyatakan dalam per-100 g dari luas total puncak semua asam lemak dalam sampel. 


\section{Analisis logam berat}

Analisislogamberatsampelmenggunakan metode atomic absorption spectrometry (AAS) berdasarkan SNI 2354.5:2011 (BSN 2011). Metode ini dilakukan berdasarkan prinsip hukum Lambert-Beert yaitu banyaknya sinar yang diserap berbanding lurus dengan kadar zat. Sampel kepiting keraca dipisahkan kedua capit dan karapasnya, dicuci bersih dengan akuades dan dibilas sebanyak tiga kali kemudian ditiriskan. Sampel kemudian diblender hingga homogen. Sampel sebanyak $1 \mathrm{~g}$ dimasukkan ke dalam labu destruksi 100 $\mathrm{mL}$, dengan ditambah $15 \mathrm{~mL} \mathrm{HNO}_{3}$ pekat dan $5 \mathrm{~mL} \mathrm{HClO}_{4}$, kemudian didiamkan pada suhu ruang selama 24 jam. Sampel didestruksi pada suhu $350{ }^{\circ} \mathrm{C} \pm 1$ jam hingga jernih, kemudian didinginkan, dan ditambah 10-20 $\mathrm{mL}$ air bebas ion, kemudian dipanaskan \pm 10 menit, kemudian diangkat dan didinginkan. Larutan tersebut dipindahkan ke dalam labu takar $100 \mathrm{~mL}$ (labu dekstruksi dibilas dengan air bebas ion dan dimasukkan ke dalam labu takar). Larutan ditambah air sampai batas tanda tera, kemudian dikocok dan disaring dengan kertas saring Whatman no.4. Filtrat dianalisis kandungan logam beratnya $(\mathrm{Cd}, \mathrm{Hg}$, $\mathrm{Pb}$ ) menggunakan AAS. Analisis kandungan logam berat mengacu pada SNI 7387:2009 yaitu tentang batas maksimum cemaran logam berat dalam pangan.

\section{HASIL DAN PEMBAHASAN Morfologi Kepiting Keraca}

Kepiting keraca merupakan hasil tangkapan samping (HTS) nelayan di kota Tarakan dengan alat tangkap pukat tarik, tepatnya di perairan Mamburungan. Rata-rata ukuran dan berat kepiting keraca jantan dan betina disajikan pada Table 1 .

Table 1 menunjukkan bahwa keraca betina memiliki bobot yang lebih berat bila dibandingkan dengan jantan. Hasil tersebut dikarenakan pengambilan kepiting keraca dilakukan pada saat musim reproduksi di awal bulan Januari ketika musim penghujan, sehingga indeks kematangan gonad akan semakin meningkat. Bobot gonad kepiting betina lebih besar bila dibandingkan dengan bobot gonad kepiting jantan. Effendie (2002), menyatakan bahwa indeks kematangan gonad akan semakin meningkat nilainya apabila mencapai batas maksimal saat kepiting akan memijah. Umumnya peningkatan bobot gonad pada kepiting jantan mencapai 5-10\% dari bobot tubuhnya, sedangkan penambahan gonad pada ikan betina mencapai 10-25\% dari bobot tubuhnya.

Kepiting keraca ditemukan di dasar laut bersubstrat berbatu, berkarang, berpasir, berlumpur, kawasan mangrove, dan lamun. Wee dan Ng (1995), menyatakan jumlah spesies Thalamita sp. yang ditemukan di perairan Indonesia lebih banyak daripada di semenanjung Malaysia dan Singapura yang hanya terdapat 17 spesies.

Ukuran tubuh genus Thalamita jantan dan betina di setiap lokasi berbeda disebabkan oleh perbedaan kondisi habitat, ketersediaan makanan, genetik dan indeks kematangan gonad. Sawusdee et al. (2009), melaporkan bahwa genus Thalamita sp. termasuk dalam kepiting yang berukuran kecil. Ukuran tubuh Thalamita sp. jantan yang ditemukan di Teluk Sikao Thailand lebih besar dibandingkan dengan betina. Lebar karapas jantan terbesar Thalamita sp. yang ditemukan di TetayamaCiba, Jepang yaitu sekitar $6,15 \mathrm{~cm}$ untuk jantan dan 5,44 cm betina. Ukuran tubuh dari genus Thalamita di setiap lokasi berbeda-beda disebabkan oleh perbedaan kondisi habitat, ketersediaan makanan, dan genetik. Kepiting keraca disajikan pada Figure 1.

\section{Komposisi Kimia Kepiting Keraca}

Analisis komposisi kimia bahan pangan sangat penting dilakukan untuk memperoleh informasi terkait kandungan gizi yang

Tabel 1 Average size and weight of mottled swimming crab (Thalamita sp.) from Tarakan

\begin{tabular}{lll}
\hline \multicolumn{1}{c}{ Parameter } & Male & Female \\
\hline Length $(\mathrm{cm})$ & $4.10 \pm 0.45$ & $3.20 \pm 0.65$ \\
Width $(\mathrm{cm})$ & $5.37 \pm 0.51$ & $3.25 \pm 0.13$ \\
Weight $(\mathrm{g})$ & $4.24 \pm 0.15$ & $4.83 \pm 0.71$ \\
\hline
\end{tabular}




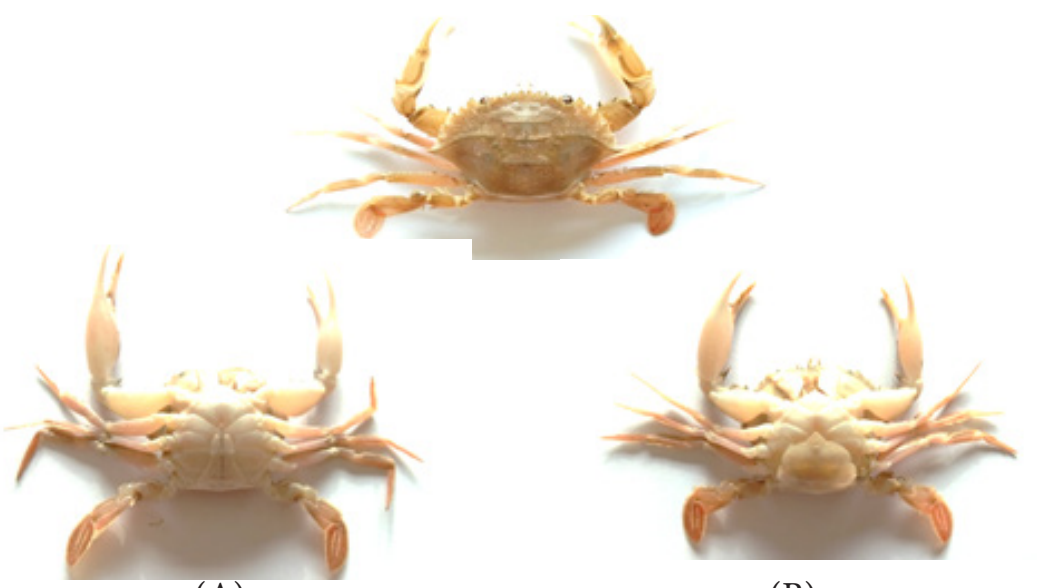

(A)

(B)

Figure 1 Thalamita sp. (A) male and (B) female

terdapat di dalam bahan pangan tersebut. Komposisi kimia yang terdapat dalam rajungan dipengaruhi oleh beberapa faktor, di antaranya musim, ukuran, tahap kedewasaan, suhu lingkungan, dan ketersediaan bahan makanan (Sudhakar et al. 2009). Hasil analisis kimia kepiting keraca basis basah disajikan pada Table 2.

Table 2 Chemical composition (wet bases) of mottled swimming crab from Tarakan

\begin{tabular}{lr}
\hline \multicolumn{1}{c}{ Parameter } & \multicolumn{1}{c}{$(\% \mathrm{w} / \mathrm{w})$} \\
\hline Moisture & $70.05 \pm 0.42$ \\
Ash & $13.02 \pm 0.35$ \\
Protein & $9.88 \pm 0.08$ \\
Lipid & $0.25 \pm 0.01$ \\
Crude fiber & $2.52 \pm 0.07$ \\
Carbohydrate & $6.84 \pm 0.19$ \\
\hline
\end{tabular}

Sampel kepiting keraca yang digunakan dalam penelitian ini adalah kepiting segar, sehingga kadar air yang diperoleh cukup tinggi, yaitu 70,05 $\pm 0,42 \%$ (Table 2). Hewan air pada umumnya memiliki kadar air berkisar antara 50-90\% berat basah. Hasil ini masih lebih rendah apabila dibandingkan dengan kadar air pada kepiting rajungan (Portunus pelagicus) yang dilaporkan Jacoeb et al. (2012), yaitu sebesar 78,47\% dan kepiting bakau (Scylla serrata) yang diperoleh Sarower et al. (2013), berkisar 75,31-78,02\%. Perbedaan kandungan kadar air ini disebabkan kepiting keraca memiliki ukuran cangkang yang lebih kecil daripada rajungan dan kepiting bakau. Amalo dan Damanik (2020), melaporkan bahwa ukuran cangkang pada kepiting dapat memengaruhi besarnya kadar air karena semakin besar cangkang, maka semakin besar juga potensi kepiting untuk menyimpan cadangan air di dalam tubuhnya. Air tersebut digunakan oleh kepiting untuk mempertahankan tubuhnya jika terjadi kekeringan saat air surut.

Kadar abu kepiting keraca pada penelitian ini diperoleh sebesar 13,02 $\pm 0,35 \%$ (Table 2), lebih tinggi dari hasil pengukuran kepiting rajungan oleh Suwandi et al. (2019). Hal ini terjadi karena sampel kepiting keraca yang dianalisis bukan hanya dagingnya saja, namun seluruh bagian tubuh kepiting keraca kecuali cangkang dan capit. Kadar abu menginterpretasikan jumlah kadar mineral dalam bahan uji (kepiting). Lesbani et al. (2011) menyatakan bahwa dalam kulit kepiting banyak terkandung oksida logam dan mineral seperti kalsium karbonat, seng, besi, dan fosfor yang diperkuat dengan tingginya nilai kadar abu dari hasil percobaannya pada kepiting bakau.

Kadar protein pada kepiting keraca segar sebesar 9,89 $\pm 0,08 \%$ (Table 2). Persentase ini masih lebih rendah bila dibandingkan dengan daging rajungan segar basis basah dari Cirebon Jawa Barat yakni 14,66 \% (Jacoeb et al. 2012) dan daging kepiting bakau yang diperoleh dari pembudidaya di Satkhira Bangladesh tanpa proses penggemukan yaitu 16,60-19,38\% (Sarower et al. 2013). Hasil pengukuran kadar protein dari kepiting keraca berkaitan dengan kadar air yang dihasilkan, karena protein berperan dalam pengikatan air dalam daging 
kepiting. Pendapat ini diperkuat oleh Amalo dan Damanik (2020), bahwa kadar protein yang rendah dapat menyebabkan rendahnya kemampuan daging dalam mengikat air. Indikasi rendahnya kadar protein pada kepiting keraca bukan hanya dari kandungan airnya saja, melainkan juga dari tingginya kadar abu yang dihasilkan. Kandungan kadar abu yang tinggi menunjukkan bahwa hanya sedikit daging sampel kepiting keraca yang digunakan, sedangkan sisanya adalah kulit yang didominasi oleh mineral sehingga menyebabkan kadar protein kepiting keraca menjadi lebih rendah.

Kadar lemak kepiting keraca segar adalah $0,25 \pm 0,01 \%$ (Table 2). Berbeda dengan protein, hasil perolehan lemak pada penelitian ini lebih tinggi daripada kepiting rajungan yakni 0,18\% (Jacoeb et al., 2012), namun lebih rendah dibandingkan dengan kepiting bakau yang ditemukan di perairan estuari yakni berkisar antara 1,17-1,47\% (Sarower et al. 2013) dan 8,5\% (Swasthikawati et al. 2014). Kepiting keraca dan rajungan yang dimaksud di sini memiliki kesamaan pada proses penangkapannya yaitu di perairan yang memiliki salinitas tinggi yakni $31,20 \pm 1,82 \mathrm{mg} / \mathrm{L}$ untuk perairan Kota Tarakan (Cahyadi dan Gusman 2017) dan 30$34 \mathrm{mg} / \mathrm{L}$ untuk perairan Desa Gebang Mekar Kabupaten Cirebon (Rakhmadi et al. 2019), sedangkan kepiting bakau hidup di perairan estuari yang memiliki rentang salinitas tinggi (eurihalin). Kemampuan hidup kepiting bakau di perairan eurhalin dipengaruhi oleh jumlah lipid/lemak dalam daging, semakin tinggi kadar lemak dalam daging, maka semakin besar kemampuan kepiting untuk beradaptasi di lingkungan perairan yang memiliki salinitas fluktuatif (estuari). Hal ini bersesuaian dengan pendapat Sitaba et al. (2017), pada media dengan beban osmotik di luar kisaran isosmotik, kepiting melakukan kerja osmotik untuk keperluan osmoregulasi. Beban osmotik yang dialami kepiting bakau sebanding dengan perbedaan osmolaritas antara media dan cairan tubuh (hemolimfe). Pernyataan tersebut memperkuat kemungkinan kadar lemak kepiting keraca yang lebih rendah dari kepiting bakau menyebabkan kepiting keraca memiliki daya toleransi yang rendah terhadap rentang salinitas yang cukup tinggi (eurihalin).

Karbohidrat merupakan salah satu makronutrien selain protein dan lemak yang berperan penting dalam pembentukan biomolekul dan sebagai sumber energi bagi kepiting. Total karbohidrat kepiting keraca yang diperoleh dari hasil perhitungan sebesar 6,85 $\pm 0,19 \%$ (Table 2). Jacoeb et al. (2012) menyatakan bahwa karbohidrat pada daging kepiting tidak mengandung serat, tetapi kebanyakan dalam bentuk glikogen. Karbohidrat pada moluska berfungsi untuk mencegah timbulnya pemecahan protein berlebihan dan kehilangan mineral, serta membantu metabolisme protein dan lemak.

Kandungan serat kasar kepiting keraca yang diperoleh dalam penelitian adalah $2,52 \pm 0,07 \%$ (Table 2). Serat kasar tersebut diduga berasal dari kulit kepiting keraca karena sampel uji yang digunakan adalah daging dan kulit (kecuali cangkang keras dan capit). Kusumawati (2014) melaporkan bahwa kandungan serat kasar pada limbah cangkang rajungan sebesar 10,89\%, lebih besar dibandingkan dengan serat kasar pada kepiting keraca. Hal ini menunjukkan adanya kemungkinan bahwa bagian cangkang dan capit kepiting keraca yang tidak diukur mengandung lebih banyak serat kasar berupa kitin.

\section{Profil Asam Lemak Kepiting Keraca}

Asam lemak merupakan senyawa nutrisi penting yang dapat memengaruhi kesehatan orang yang mengonsumsinya. Hal ini tentu saja bergantung pada berbagai faktor seperti sumber dan jenis asam lemak yang dikonsumsi (Pratama et al. 2018). Analisis profil asam lemak bertujuan menentukan komposisi asam lemak jenuh dan asam lemak tidak jenuh yang terdiri dari asam lemak tidak jenuh tunggal (monounsaturated fatty acid/ MUFA) dan asam lemak tidak jenuh majemuk (polyunsaturated fatty acid/PUFA). Persentase profil asam lemak kepiting keraca basis basah disajikan pada Table 3 .

Table 3 menunjukkan bahwa kepiting keraca segar mengandung asam lemak jenuh (SFA) sebesar 12,64\%, asam lemak tak jenuh tunggal (MUFA) 5,46\% dan asam lemak tak jenuh majemuk (PUFA) yaitu 8,73\%. Jumlah 
asam lemak yang teridentifikasi adalah $26,83 \%$ dan yang tidak teridentifikasi sebesar 73,17\%. Komposisi asam lemak yang bervariasi ini dipengaruhi oleh faktor eksternal dan faktor internal. Ozyurt et al. (2006), menyatakan bahwa komposisi asam lemak yang bervariasi dipengaruhi oleh beberapa faktor, di antaranya adalah letak geografis, pergantian musim, salinitas lingkungan. Bija et al. (2017), menegaskan perbedaan pada profil SFA, MUFA, dan PUFA juga dapat dipengaruhi oleh daerah penangkapan, waktu penangkapan, dan ukuran. Ould $e t$ al. (2003) melaporkan bahwa kondisi lingkungan memengaruhi komposisi PUFA, semakin dingin air maka semakin tinggi kandungan PUFA nya. Helmizuryani dan Pratama (2018), menyatakan ukuran ikan dipengaruhi oleh tingkat kematangan gonad karena asam lemak esensial merupakan salah satu ciri dalam tingkat kematangan gonad ikan

Asam lemak jenuh adalah asam lemak yang hanya memiliki ikatan tunggal pada rantai hidrokarbonnya. Hasil analisis menunjukkan kandungan asam lemak jenuh pentadekanoat pada kepiting keraca memiliki jumlah yang paling tinggi yaitu 6,79\% (Table 3). Skeaff et al. (2009), menyatakan bahwa asam pentadekanoat merupakan asam lemak rantai panjang yang jarang dijumpai dalam sistem biologis sehingga lebih berguna sebagai standar internal atau biomarker.

Asam lemak tak jenuh tunggal adalah asam lemak yang memiliki satu ikatan rangkap pada rantai hidrokarbonnya. Hasil analisis pada Table 3 menunjukkan bahwa

Tabel 3 Fatty acid profile of mottled swimming crab (Thalamita sp.) from Tarakan

\begin{tabular}{|c|c|c|}
\hline FattyAcid & Structure & $\% \mathrm{w} / \mathrm{w}$ \\
\hline Lauric Acid & $\mathrm{C} 12: 0$ & 0.04 \\
\hline Myristic Acid & C14:0 & 0.62 \\
\hline Pentadecanoic Acid & C15:0 & 6.79 \\
\hline Palmitic Acid & $\mathrm{C} 16: 0$ & 0.54 \\
\hline Heptadecanoic Acid & $\mathrm{C} 17: 0$ & 4.59 \\
\hline Arachidic Acid & C20:0 & 0.04 \\
\hline Lignoceric Acid & C24:0 & 0.02 \\
\hline SFA Total & & 12.64 \\
\hline Palmitoleic Acid & C16:1 & 0.32 \\
\hline Cis-10-Heptadecanoic Acid & C17:1 & 3.77 \\
\hline Oleic Acid & $\mathrm{C} 18 \mathrm{~s} \ln 9 \mathrm{c}$ & 0.74 \\
\hline Erucic Acid Methyl Ester & $\mathrm{C} 22: \ln 9$ & 0.03 \\
\hline Cis-11-Eicosenoic Acid & C20:1 & 0.60 \\
\hline MUFA Total & & 5.46 \\
\hline Linoleic Acid & $\mathrm{C} 18 ; 2 \mathrm{n} 6 \mathrm{c}$ & 0.41 \\
\hline Gamma-Linolenic Acid & C18:3n6 & 0.32 \\
\hline Linolenic Acid & $\mathrm{C} 18 ; 3 \mathrm{n} 3$ & 0.07 \\
\hline Cis-11,14-Eicosedienoic Acid & $\mathrm{C} 20: 2$ & 2.76 \\
\hline Cis-8,11,14,17-Eicosatrienoic Acid Methyl Ester & $\mathrm{C} 20: 3 \mathrm{n} 3$ & 0.16 \\
\hline Cis-8,11,14,-Eicosetrienoic Acid & C20:3n6 & 0.12 \\
\hline Arachidonic Acid & C20:4n6 & 2.16 \\
\hline Cis-5,8,11,14,17-Eicosapentaenoic Acid & $\mathrm{C} 20: 5 \mathrm{n} 3$ & 2.73 \\
\hline PUFA Total & & 8.73 \\
\hline
\end{tabular}


asam lemak tak jenuh tunggal yang paling banyak ditemukan pada kepiting keraca adalah cis-10-heptadekanoat yaitu 3,77\%. Fukuzawa et al. (2008) melaporkan bahwa jenis asam lemak ini terbukti memiliki beberapa aktivitas penghambatan terhadap sel-sel kanker manusia HL-60 meskipun masih kurang dibandingkan dengan asam lemak jenuh rantai panjang lainnya.

Asam lemak tidak jenuh majemuk adalah jenis asam lemak yang memiliki 2 hingga lebih ikatan rangkap pada rantai karbonnya. Asam lemak tidak jenuh majemuk yang dominan adalah asam cis 11,14-eikosadienoat 2,76\% (Table 3). Menurut Huang et al. (2011), asam eikosadienoat merupakan salah satu jenis asam lemak omega-6 yang ditemukan terutama pada jaringan hewan. Asam lemak ini mampu memodulasi metabolisme asam lemak tak jenuh majemuk dan mengubah respons makrofag terhadap stimulasi inflamasi. Weta (2016) menjelaskan bahwa asam lemak esensial memodulasi respons imun melalui satu atau lebih dari tiga mekanisme molekuler utama, di antaranya adalah mengubah komposisi dan fungsi membran sel, memodifikasi produksi eikosanoid, dan mengubah biosintesis sitokin. Sitokin ini bersifat sebagai mediator untuk mengaktivasi makrofag dan meningkatkan respons imunitas diperantarai sel (cell mediated immunity) untuk melawan patogen intraseluler.

Asam lemak omega-6 sama pentingnya dengan asam lemak omega-3. Kedua jenis asam lemak ini merupakan prekursor untuk mediator lipid yang disebut eikosanoid. Secara umum, eikosanoid yang diperoleh dari omega-3 bersifat anti inflamasi, sedangkan eikosanoid dari omega- 6 bersifat proinflamasi (Medeiros et al. 2015). Ketidakseimbangan rasio asupan omega-3 dan omega-6 dapat meningkatkan faktor risiko penyakit kardiovaskular. Perbandingan asupan omega-3 dan omega-6 yang direkomendasikan adalah untuk omega-3 sebanyak 1,1-3 g per hari, sedangkan omega-6 yaitu 10-13 g per hari (Meyer et al. 2003).

Asam lemak yang terdapat di dalam tubuh organisme perairan, dapat memengaruhi aroma komoditas secara keseluruhan karena adanya senyawa-senyawa volatil yang dihasilkan. Penelitian yang telah dilakukan oleh Prasetyo et al. (2014) menyatakan bahwa pada kepiting bakau yang dikukus, terbentuk senyawa-senyawa volatil karbonil maupun asamasam keton. Sebagian besar senyawa volatil yang dihasilkan kepiting keraca melibatkan asam lemak tak jenuh dan asam lemak jenuh dalam proses reaksinya. Lazo et al. (2017), menjelaskan bahwa senyawa volatil dapat berasal dari golongan keton, aldehid, dan alkohol yang merupakan hasil reaksi dengan melibatkan asam lemak. Senyawa volatil yang termasuk dalam gugus hidrokarbon timbul karena oksidasi termal pada asam lemak tidak jenuh serta pemisahan rantai karbon asam lemak.

\section{Kandungan Logam Berat Kepiting Keraca}

Cemaran logam berat seperti $\mathrm{Cd}, \mathrm{Hg}$ dan $\mathrm{Pb}$ dapat terakumulasi dalam tubuh biota perairan, termasuk kepiting. Kepiting yang tercemar logam berat dan melebihi baku mutu dapat membahayakan kesehatan. Selain itu, logam berat juga dapat merugikan secara ekonomi. Menurut Barokah et al. (2019), pencemaran logam berat di laut dapat mengganggu proses metabolisme biota. Kondisi ini dapat mengakibatkan kepiting kehilangan bobot tubuhnya dan menghambat pertumbuhan, sehingga akan merugikan dari segi ekonomi.

Pengujian logam berat pada kepiting keraca bertujuan untuk memperoleh bahan baku yang aman dari cemaran kimia sebelum dijadikan produk olahan dan dipasarkan kepada konsumen. Hasil analisis pengujian logam berat disajikan pada Table 4 .

Table 4 Heavy metal of mottled swimming swimming crab from Tarakan

\begin{tabular}{lrr}
\hline Heavy metal & $\begin{array}{c}\text { Results } \\
(\mathrm{mg} / \mathrm{kg})\end{array}$ & \multicolumn{1}{c}{$\begin{array}{c}{ }^{*} \text { ShI } \\
\text { Threshold } \\
(\mathrm{mg} / \mathrm{kg})\end{array}$} \\
\hline Cadmium $(\mathrm{Cd})$ & 0.0005 & $<0.1$ \\
Mercury $(\mathrm{Hg})$ & 0.0003 & $<0.5$ \\
Lead $(\mathrm{Pb})$ & 0.0132 & $<0.2$ \\
\hline${ }^{*}$ SNI 7560.1:2010 & &
\end{tabular}

Hasil pengujian kandungan logam $\mathrm{Cd}, \mathrm{Hg}$ dan $\mathrm{Pb}$ pada kepiting keraca masih berada di bawah baku mutu SNI 7560.1: 2010 (Table 4). 
Menurut Adriansyah et al. (2019), kandungan logam dalam biota bergantung pada habitat dari biota itu sendiri. Lokasi penangkapan kepiting keraca adalah di perairan sekitar Kota Tarakan yang masih jauh dari berbagai industri seperti tekstil, pupuk, cat yang memungkinkan pembuangan limbahnya dapat memicu pencemaran lingkungan perairan. Kepiting keraca yang diperoleh dari perairan sekitar Kota Tarakan tergolong aman untuk dikonsumsi.

Akumulasi logam berat dapat terjadi karena proses bioakumulasi secara terusmenerus dan proses biomagnifikasi melalui rantai makanan pada hewan air (Connell dan Miller 1995). Berdasarkan sifat akumulatif tersebut, meskipun kandungan $\mathrm{Cd}, \mathrm{Hg}$, dan $\mathrm{Pb}$ pada kepiting keraca masih tergolong rendah dan di bawah ambang batas yang ditetapkan oleh SNI, adanya residu logam berat harus tetap diwaspadai mengingat dampaknya yang buruk bagi kesehatan.

\section{KESIMPULAN}

Komposisi kimia kepiting keraca basis basah merupakan bahan baku bergizi serta aman dari cemaran logam berat. Kandungan logam berat $\mathrm{Cd}, \mathrm{Hg}$ dan $\mathrm{Pb}$ kepiting keraca masih berada di bawah baku mutu SNI sehingga aman digunakan sebagai bahan baku produk olahan.

\section{UCAPAN TERIMA KASIH}

Terimakasih kepada Direktorat Riset dan Pengabdian Masyarakat Direktorat Jendral Penguatan Riset dan Pengembangan Kementrian Riset, Telnologi dan Pendidikan Tinggi sesuai dengan kontrak pengabdian 050/ SP2H/PPM/DRPM/2020 selaku penyandang dana untuk terlaksananya penelitian ini.

\section{DAFTAR PUSTAKA}

[AOAC] Association of Official Analytical Chemists. 2005. Official Methods of Analysis of the Association of Chemist. Arlington (US): The Association of Official Analytical Chemist, Inc.

[BSN] Badan Standardisasi Nasional. 1991. Penentuan Kadar Karbohidrat. SNI No.012370. Jakarta (ID): Badan Standardisasi Nasional.
[BSN] Badan Standardisasi Nasional. 1992. Penentuan Serat Kasar. SNI No.012891. Jakarta (ID): Badan Standardisasi Nasional.

[BSN] Badan Standardisasi Nasional. 2006a. Penentuan Kadar Air. SNI No. 0123542. Jakarta (ID): Badan Standardisasi Nasional.

[BSN] Badan Standardisasi Nasional. 2006b. Penentuan Kadar Lemak. SNI No. 0123543. Jakarta (ID): Badan Standardisasi Nasional.

[BSN] Badan Standardisasi Nasional. 2006c. Penentuan Kadar Protein. SNI No. 0123544. Jakarta (ID): Badan Standardisasi Nasional.

[BSN] Badan Standardisasi Nasional. 2009. Batas Maksimum Cemaran Logam Berat dalam Pangan. SNI No 7387: 2009. Jakarta (ID): Badan Standardisasi Nasional.

[BSN] Badan Standardisasi Nasional. 2010. Batas Maksimum Cemaran Logam Berat dalam Pangan. SNI No 7560:2010. Jakarta (ID): Badan Standardisasi Nasional.

[BSN] Badan Standardisasi Nasional. 2011. Batas Maksimum Cemaran Logam Berat Timbal dalam Pangan. SNI No 2354: 2011. Jakarta (ID): Badan Standardisasi Nasional.

Adriansyah M, Fayzun M, Ardillah NS, Peri Y, Maulianawati D, Irawati H. 2019. Monitoring kualitas air temporal dan uji logam pada kerang kapah (Meretrix meretrix) di Pantai Amal Lama Kota Tarakan. Jurnal Harpodon Borneo. 12(1): 48-56.

Agus, Asbar L. 2012. Komposisi hasil tangkapan perikanan tugu di perairan kota Tarakan. Jurnal Harpodon Borneo. 5(1): 83-90.

Amalo D, Damanik DER. 2020. Analisis kandungan protein pada kepiting bakau (Scylla serrata) jantan dan betina di pantai Silawan Kecamatan Tasifeto Timur Kabupaten Belu. Jurnal Biotropikal Sains. 17(3):77-83.

Anggorowati DA. 2014. Community structure of crustacean fauna at the intertidal zone of west Lombok. Jurnal Zoologi Indonesia. 23(2): 92-100.

Anggraeni P, Elfidasari D, Pratiwi R. 2015. 
Brachyuran crab distribution in Tikus Island, Pari Island group, Seribu Islands. Prosiding Seminar Nasional Masyarakat Biodiversitas Indonesia; 2015 Maret 21; Yogyakarta, Indonesia. Yogyakarta (ID): UNS. 213-221.

Barokah GR, Dwiyitno, \& Nugroho I. 2019. Kontaminasi logam berat $(\mathrm{Hg}, \mathrm{Pb}$, dan Cd) dan batas aman konsumsi kerang hijau (Perna viridis) dari perairan Teluk Jakarta di musim penghujan. Jurnal Pascapanen dan Bioteknologi Kelautan dan Perikanan. 14(2): 95-106.

Bija S, Suseno SH, Uju. 2017. Pemurnian minyak ikan sardin dengan tahapan degumming dan netralisasi. Jurnal Pengolahan Hasil Perikanan Indonesia. 20(1):143-152.

Bonte SB, Firdaus M. 2012. Perbedaan soaking time terhadap hasil tangkapan pada perikanan tugu (trammel net) di perairan timur Kota Tarakan. Jurnal Harpodon Borneo. 5(2): 147-159.

Cahyadi J, Gusman E. 2017. Analisis produktivitas primer perairan pantai amal lama Kota Tarakan bagi pengembangan budidaya rumput laut. Jurnal Harpodon Borneo. 10(1):45-55.

Connell DW, Miller GJ. 1995. Kimia dan Ekotoksikologi Pencemaran. Jakarta (ID): Universitas Indonesia Press.

Effendie. 2002. Biologi Perikanan. Bogor (ID):Yayasan Pustaka Nusantara.

Firdaus M. 2010. Hasil tangkapan dan laju tangkap unit perikanan pukat tarik, tugu, dan kelong. Jurnal Makara Teknologi. 14(1): 22-28.

Fukuzawa M, Yamaguchi R, Hide I, Chen Z, Hirai Y, Sugimoto A, Yasuhara T, Nakata Y. 2008. Possible involvement of long chain fatty acids in the spores of Ganoderma lucidum (Reishi Houshi) to its anti-tumor activity. Biological and Pharmaceutical Bulletin. 31(10): 1933-1937.

Hamid A, Wardiatno Y, Irawati N. 2019. Biological aspects of genus Thalamita Latreille, 1829 (Decapoda: Portunidae) in Lasongko Bay, Southeast Sulawesi, Indonesia. Aquaculture, Aquarium, Conservation and Legislation. 12(4): 1335-1348.
Helmizuryani dan Pratama MA. 2018. Pengaruh pemberian minyak jagung yang ditambahkan pada pakan terhadap pematangan gonad ikan betok (Anabas testudineus). Journal of Fisheries. 7(1): 1723.

Huang J, Huang L, Chen YJ, Austin E, Devor CE, Roegiers F, Hong Y. 2011. Differential regulation of adherens junction dynamics during apical-basal polarization. Journal of Cell Science. 124(23): 4001-4013.

Jacoeb AM, Nurjanah, Lingga LAB. 2012. Karakteristik protein dan asam amino daging rajungan (Portunus pelagicus) akibat pengukusan. Jurnal Pengolahan Hasil Perikanan Indonesia. 15(2): 156163.

Kanna I. 2002. Budidaya Kepiting Bakau: Pembenihan dan Pembesaran. Yogyakarta (ID): Kanisius.

Kasry A. 1996. Budidaya Kepiting Bakau dan Biologi Ringkas. Jakarta (ID): Bhatara.

Kusumawati. 2014. Evaluasi Nilai Nutrisi Limbah Rajungan dan Kajian Potensi Sebagai Pakan Unggas.[Skripsi]. Mataram (ID): Universitas Mataram.

Lazo O, Guerrero L, Alexi N, Grigorakis K, Claret A, Perez ZA, Bou R. 2017. Sensory characterization, physico-chemical properties and somatic yields of five emerging fish species. Food Research International. 100: 396-406.

Lesbani A, Yusuf S, Melviana, RAM. 2011. Karakterisasi kitin dan kitosan dari cangkang kepiting bakau (Scylla serrata). Jurnal Penelitian Sains. 14(3): 32-36.

Medeiros, Denis M, Wildman RE. 2015. Advanced of Human Nutrition. 3rd ed. Burlington (US): Jones and Bartlett Learning.

Meyer, Barbara J. 2003. Dietary intakes and food sources of omega- 6 and omega- 3 polyunsaturated fatty acids. United States (US): AOCS Press.

Muhd-Farouk H, Amin-Safwan A, Arif MS, Ikhwanuddin M. 2017. Biological information and size at maturity of male crenate swimming crab, Thalamita crenata from Setiu Wetlands, Terengganu coastal waters. Journal of Sustainability Science and Management. 12(2):119-127. 
Norman CP. 1996. Reproduction biology and evidence for hard-female mating in the brachyuran crab Thalamita sima (Portunidae). Journal of Crustacean Biology. 16(6): 656-662.

Ould EKMV, Branathan G, Siau Y, Miralles J, Gaydou EM. 2003. Fatty aciddistribution in muscle, liver and gonads of rays (Dasyatis marmorata, Rhinobatos cemiculus, and Rhinoptera marginata) from the East Tropical Atlantic Ocean. Journal of Agricultural and Food Chemistry. 51: 1942-1947.

Ozyurt G, Duysak O, Akamca E, Tureli C. 2006. Seasonal changes of fatty acid of cuttlefish Sepia officinalis. (Mollusca: Cephalopoda) in the north eastern Mediterranean sea. Food Chemistry. 95: 382-385.

Prasetyo M, Riyadi PH, Anggo AD. 2014. Pengaruh waktu pengukusan terhadap kualitas kepiting bakau (Scylla serrata) presto dengan alat "Ttsr". Jurnal Pengolahan dan Bioteknologi Hasil Perikanan. 3(3): 5-19.

Pratama RI, Rostini I, Rochima E. 2018. Profil asam amino, asam lemak dan komponen volatil ikan gurame segar (Osphronemus gouramy) dan kukus. Jurnal Pengolahan Hasil Perikanan Indonesia. 21(2): 218231.

Pratiwi R, Widyastuti E. 2013. Distributional patterns and zonation of crustaceans mangrove in Lampung Bay. Journal Zoo Indonesia. 22(1): 11-21.

Rachmadi A, Astuty S, Gumilar I, Pamungkas W. Kesesuaian kondisi bioekologi ekosistem mangrove sebagai kawasan rehabiliasi mangrove di Desa Gebang Mekar Kabupaten Cirebon Jawa Barat. Jurnal Perikanan dan Kelautan. 10(1): 1-7.

Sarower G, Bilkis S, Rauf A, Khanam M, Islam S. 2013. Comparative biochemical composition of natural and fattened mud crab Scylla serrata. Journal of Scientific Research. 5(3): 545-553.

Sawusdee A, Songrak A. 2009. Population dynamics and stock assessment of blue swimming crab (Portunus pelagicus linnaeus, 1758) in the coastal area of trangprovince, Thailand. Journal Science and Technology. 6(2): 189-202.

Sitaba RD, Salindeho IRN, Kusen DJ. 2017. Pengaruh perbedaan salinitas terhadap pertumbuhan kepiting bakau (Scylla serrata). Jurnal Budidaya Perairan. 5(2): 8-14.

Skeaff CM, Miller J. 2009. Dietary fat and coronary heart disease: summary of evidence from prospective cohort and randomised controlled trials. Animals of Nutrition Metabolism Journal. 55 (1): 173-201.

Sudhakar M, Manivannan K, Soundrapandian P. 2009. Nutritive value of hard and soft shell crabs of Portunus sanguinolentus (Herbst). Journal of Animal and Veterinary Advances. 1(2): 44-48.

Sugiyono. 2007. Metode Penelitian Kuantitatif Kualitatif. Bandung (ID): Alfabeta Pr.

Suwandi R, Nurjanah, Maharani S. 2019. Perbedaan waktu penanganan terhadap bobot, komposisi proksimat, dan asam amino rajungan kukus. Jurnal Pengolahan Hasil Perikanan Indonesia. 22(1): 128135.

Swasthikawati S, Pratiwi R, Trijoko. 2014. Kandungan lemak total, kalsium (Ca), besi $(\mathrm{Fe})$ dan seng $(\mathrm{Zn})$ pada kepiting (Scylla serrata, Forsskal) selama proses ekdisis. Jurnal Sain Veteriner. 32(2): 242249.

Wahyudi AJ. 2008. Phenetic study on genus of Thalamita Latreille, 1829 (Crustacea: Decapoda: Brachyura: Portunoidea: Portunidae) based on morphological diagnosys in "Faune de Madagascar XVI". Jurnal Oseanologi. 1(1):1-10.

Wee DPC, Ng PKL. 1995. Swimming crabs of the genera Charybdis De Haan, 1833, and Thalamita Latreille, 1829 (Crustacea: Decapoda: Brachyura: Portunidae) from peninsular Malaysia and Singapore. The Raffles Bulletin of Zoology. 1:1-128.

Weta I. 2016. Peran asam lemak tidak jenuh majemuk omega-3 (ALTJM N-3) dalam pengendalian penyakit degeneratif. [Skripsi]. Denpasar (ID): Universitas Udayana. 